\title{
MEMORIAL
}

\section{ANNA-STINA MAGNUSSON EDHORN}

\section{(1915-1992)}

Paleontologist Anna-Stina Magnusson Edhorn passed away January 31, 1992, at age 76 from a lung ailment. Born in Sweden in 1915 and immigrated to Canada in 1954, Anna-Stina did not follow the standard life of a researcher. She started her professional career as a technical assistant in pharmacy in Calgary. Anna-Stina was interested in minerals, a hobby that led to a position cataloging minerals at the University of Toronto. Under the tutelage of Professor W. W. Moorehouse, she became fascinated with his work on the Precambrian of Canada. In 1965, they collected a "car full" of Precambrian rocks from Thunder Bay, Ontario, and her job was to analyze the thin sections for fossils. At this time, Precambrian fossils were just beginning to be recognized. She discovered a magnificent flora and shared it with the late Elso Barghoorn, who had published on Precambrian organisms.

In 1970, Anna-Stina moved to Brock University where she was later appointed as a Research Associate. She published these Precambrian fossil findings in the "Proceedings of the Geological Association of Canada" in 1974. In this publication, she named six new genera and 11 new species of cyanobacteria and algae and included a photograph of a possible worm. Having decided to earn a B.S., Anna-Stina returned to Sweden and was awarded her degree in 1974 , at age 59, at the University of Stockholm.

Anna-Stina also published on thin section evidence for grazing activity on Lower Cambrian stromatolites in Newfoundland; the preserved structures were so delicate that she was able to delineate changes in growth patterns. In late Proterozoic copper-bearing rocks from Zaire, she found evidence for microbial precipitation of sulfide mineralization. In Lower Cambrian rocks from Newfoundland, she documented competitive exclusion between cyanobacteria and archaeocyathids.

Anna-Stina finally gave in to academic pressure to continue schooling for credibility; at the time of her death, she was enrolled in a Ph.D. program at the University of Stockholm, working on the protozoan nature of Kakabekia. An abstract of her thesis is to be published by the University of Luchnow, India.

Anna-Stina is survived by her husband, Allard Edhorn. In the last 10 years of her life, she and Allard were active in environmental problems in Thornton, Ontario. Anna-Stina willed her collection of thin sections, books, reprints, and photographs to Brock University. All of those who were touched by her gentleness, generosity, and lifelong enthusiasm about early organisms grieve her passing.

Eleanora I. Robbins

U.S. Geological Survey

National Center MS 956

Reston, VA 22092 